\title{
PENGARUH COGNITIVE BIAS DAN EMOTIONAL BIAS TERHADAP KEPUTUSAN PENEMPATAN DANA UNTUK MODAL KERJA PADA USAHA KECIL MENENGAH (UKM) DI PULAU LOMBOK PADA MASA PANDEMI COVID 19
}

\author{
Siti Aisyah Hidayati ${ }^{1}$, Sri Wahyulina ${ }^{2}$, Embun Suryani ${ }^{3}$ \\ 1,2,3Fakultas Ekonomi dan Bisnis Universitas Mataram \\ Email: sitiaisyahhidayati@unram.ac.id
}

\begin{tabular}{|c|c|}
\hline ARTICLE INFO & ABSTRACT \\
\hline $\begin{array}{l}\text { Keywords: } \\
\text { Cognitive bias, emotional bias, fund } \\
\text { allocation decision for working capital } \\
\text { How to cite: } \\
\text { Hidayati, Siti Aisyah., Wahyulina, Sri., } \\
\text { Suryani, Embun., (2022). Pengaruh } \\
\text { Cognitive Bias Dan Emotional Bias } \\
\text { Terhadap Keputusan Penempatan Dana } \\
\text { Untuk Modal Kerja Pada Usaha Kecil } \\
\text { Menengah (UKM) Di Pulau Lombok } \\
\text { Pada Masa Pandemi Covid 19. } \\
\text { JMM UNRAM, 11(1), 21-38 } \\
\text { DOI: } \quad \text { : } 10 \text { Februari } 2022 \\
\text { 10.29303/jmm.v11i1.697 } \\
\text { Dikumpulkan: 20 Januari } 2022 \\
\text { Direvisi } \\
\text { Dipublikasi } \quad 16 \text { Februari } 2022\end{array}$ & $\begin{array}{l}\text { This study aims to analyze the Effect of Cognitive Bias and } \\
\text { Emotional Bias on Fund Allocation Decision for Working } \\
\text { Capital in Small and Medium Enterprises (SMEs) on Lombok } \\
\text { Island during the Covid } 19 \text { Pandemic. The theoretical } \\
\text { contribution of this research is expected to contribute to science } \\
\text { and the development of behavioral finance theory that related to } \\
\text { financial decision making and company performance in Small } \\
\text { and Medium Enterprises (SMEs). In addition, behavioral } \\
\text { finance is also expected to be the subject of financial } \\
\text { management courses. Furthermore, the practical contribution } \\
\text { of this research is expected to provide input, suggestions and } \\
\text { recommendations to the policy makers of the NTB Provincial } \\
\text { Government in making policies related to the development of } \\
\text { SMEs. } \\
\text { This research is a quantitative approach-based research, with } \\
\text { the type of explanatory research. The research population is all } \\
\text { SMEs located on the island of Lombok. The sampling technique } \\
\text { is carried out by non-probability sampling, which uses } \\
\text { judgment sampling, namely selecting SMEs that are engaged } \\
\text { in the pottery industry and have already exported. From the } \\
\text { existing population, there are 34 (thirty four) SMEs that can be } \\
\text { taken as samples. Respondents in this study are the owners of } \\
\text { each of these SMEs. The data collection technique used in this } \\
\text { research is using a questionnaire. To achieve the research } \\
\text { objectives and hypothesis testing, the data obtained will be } \\
\text { processed according to the needs by using the statistical tool } \\
\text { GSCA (Generalized Structured Component Analysis). } \\
\text { The results showed that Cognitive Bias and Emotional Bias had } \\
\text { a positive and significant impact on fund allocation decision for } \\
\text { Working Capital in Small and Medium Enterprises (SMEs) on } \\
\text { Lombok Island during the Covid 19 Pandemic. This was } \\
\text { motivated by the age of most of the respondents of productive } \\
\text { age, mostly male, the education level is mostly high school and } \\
\text { college and the length of business is more than 15 (fifteen) } \\
\text { years. }\end{array}$ \\
\hline
\end{tabular}




\section{PENDAHULUAN}

Pengambilan keputusan merupakan fenomena kompleks yang meliputi semua aspek kehidupan. Pengambilan keputusan investasi dilakukan secara rasional dalam memaksimalkan utilitasnya. Para investor secara rata-rata memanfaatkan informasi akuntansi keuangan sebagai pertimbangan dalam keputusan investasinya (Puspitaningtyas, 2012). Investor yang rasional akan melakukan analisis dalam proses pengambilan keputusan investasi. Analisis yang dilakukan antara lain dengan mempelajari laporan keuangan perusahaan. Tujuannya ialah keputusan investasi yang diambil akan memberikan kepuasan yang optimal.

Pada kenyataannya seringkali kita temukan bahwa individu berperilaku tidak rasional dan membuat kesalahan sistematis atas peramalan yang mereka lakukan. Apalagi dihadapkan dengan keadaan perekonomian yang menurun akibat pandemi Covid 19. Para pelaku keuangan mulai menyadari bahwa individu dapat mengambil keputusan yang tak rasional. Pengertian yang salah terhadap informasi akan mempengaruhi hasil investasi yang pada akhirnya mempengaruhi kekayaaan yang dimiliki investor.

Dalam teori keuangan tradisional banyak mengabaikan aspek-aspek psikologi dalam proses pengambilan keputusan investor (Ricciardi dan Simon, 2000). Adanya alasan ini, perilaku investor banyak yang tidak bisa dijelaskan dalam konteks teori keuangan tradisional. Ketidakmampuan teori keuangan tradisional untuk menjelaskan anomali dalam fenomena pasar modal dan pasar uang, maka para peneliti keuangan mulai mengaitkan fenomena yang ada dengan aspek perilaku (Behavioral Finance).

Behavioral Finance dapat didefinisikan sebagai aplikasi dari psikologi dalam disiplin ilmu keuangan untuk pengambilan keputusan keuangan di dalam rumah tangga, pasar dan organisasi. Pompian (2006) mengkategorikan bias psikologis dalam dua kategori yaitu Cognitive Bias dan Emotional Bias. Pada penelitian ini Cognitive Bias yang digunakan adalah Overconfidence, Cognitive Dissonance dan Illusion of Control, sedangkan Emotional Bias menggunakan Loss Aversion, Regret Aversion dan Status Quo. Berdasarkan pelaku pengambilan keputusan, lingkup keuangan perilaku dapat dikelompokkan menjadi empat kategori meliputi perilaku investor di pasar modal, perilaku manajer dalam pengambilan keputusan keuangan, perilaku aparatur pemerintah dalam pengelolaan keuangan negara dan perilaku rumah tangga dalam pengelolaan keuangan (Supramono, dkk., 2010:18). Berdasarkan hal tersebut, Usaha Kecil dan Menengah (UKM) termasuk dalam objek yang dapat diteliti dengan melihat perilaku manajer dalam pengambilan keputusan dan merupakan financial institution (Gumanti, 2009:8). Pengambilan keputusan yang digunakan dalam penelitian ini adalah keputusan investasi berupa keputusan penempatan dana untuk modal kerja pada UKM.

UKM merupakan organisasi yang mempunyai kepentingan terhadap behavioural finance. Berbagai faktor kelemahan internal yang mempengaruhi kinerja dan keberhasilan atau kegagalan usaha kecil dan menengah, diantaranya ketidakmampuan di dalam manajemen, lemahnya kemampuan dalam pengambilan keputusan, kurang pengalaman, lemahnya pengawasan keuangan, serta skala usaha yang terlalu kecil (Idrus, 1999:18).. Lemahnya kemampuan dalam pengambilan keputusan berkaitan dengan behavioral financial pengusaha UKM dalam pengambilan keputusan sehingga akan berpengaruh terhadap keberlangsungan hidup perusahaan. Penelitian yang telah dilakukan berkaitan dengan pengaruh cognitive bias terhadap pengambilan keputusan investasi yaitu Qadri and Shabbir (2014) yang menyatakan illusion of control dan overconfidence berpengaruh positif dan signifikan terhadap keputusan investasi. Hasil ini berbeda dengan penelitian Wulandari dan Iramani (2014) yang menyatakan 
bahwa overconfidence tidak berpengaruh terhadap pengambilan keputusan investasi. Sedangkan yang berkaitan dengan emotional bias yaitu Khilar and Singh (2020) yang menyatakan emotional bias berpengaruh terhadap keputusan investasi, demikian juga penelitian Duxbury (2015) yang menyatakan emotional bias berpengaruh positif dan signifikan terhadap pengambilan keputusan investasi. Hasil yang berbeda ditunjukkan oleh Kartini dan Nuris (2015) yang menyatakan bahwa emotional bias berpengaruh negatif terhadap pengambilan keputusan investasi.

Beberapa penelitian behavioral finance selama ini lebih diarahkan untuk menganalisis kaitan faktor psikologis tertentu dengan keputusan keuangan, yaitu Persepsi dan Faktor Psikologis dalam Pengambilan Keputusan Hutang (Supramono dan Putlia, 2010), Penelitian lain yang juga berkaitan dengan behavioral finance yang ada di UKM seperti Mental Accounting dan Dampaknya Terhadap Kinerja Perusahaan Melalui Penempatan Modal Kerja Pada Usaha Kecil Dan Menengah Di Pulau Lombok (Hidayati, Wahyulina, Wardani dan Negara, 2015), Pengaruh Risk Attitudes Terhadap Kinerja Perusahaan Melalui Keputusan Penempatan Modal Kerja (Hidayati, Wahyulina dan Widiana, 2016), Behavioral Finance Dan Pengaruhnya terhadap Pengambilan Keputusan Hutang (Hidayati, Wahyulina, Suryani, 2017) dan Pengaruh Behavioral Finance Terhadap Kinerja Perusahaan Melalui Pengambilan Keputusan Hutang (Studi Pada Usaha Kecil Dan Menengah (UKM) Di Pulau Lombok) (Hidayati, Wahyulina dan Suryani, 2018). Ada perbedaan penelitian ini dengan penelitian sebelumnya yaitu penelitian ini dilakukan pada kondisi Pandemi Covid 19. Berdasarkan fenomena, research gap dan kondisi Pandemi Covid 19 maka perlu dilakukan penelitian " Pengaruh Cognitive Bias dan Emotional Bias terhadap Keputusan Penempatan Dana untuk Modal Kerja pada Usaha Kecil Menengah (UKM) di Pulau Lombok pada Masa Pandemi Covid 19".

\section{TUJUAN PENELITIAN}

Tujuan penelitian ini adalah untuk menganalisis Cognitive Bias dan Emotional Bias terhadap Keputusan Penempatan Dana untuk Modal Kerja pada UKM di Pulau Lombok pada masa Pandemi Covid 19.

\section{TINJAUAN PUSTAKA DAN KAJIAN EMPIRIK}

\subsection{Pengertian Behavioural Finance}

Banyak investor yang tidak menyadari bahwa faktor psikologis dalam dirinya mempengaruhi keputusannya dalam mengambil keputusan investasi.. Menurut De Bondt, et al. (2008) menyatakan "Behavioral finance is the study of how psychology impacts financial decisions in households, market and organizations", yang artinya studi tentang bagaimana psikologi berdampak pada keputusan-keputusan keuangan di dalam rumah tangga, pasar dan organisasi. Sedangkan menurut Pompian (2006) Behavioral Finance, commonly defined as the application of psychology to finance. Shefrin's (2005) dalam Forbes (2009) Behavioral finance is the study of how psychological phenomena impact financial behavior. Sedangkan menurut Lintner (1998:7), behavioural finance "the study of humans interpret and act on information to make informed investment decisions" artinya, keuangan perilaku merupakan ilmu yang mempelajari bagaimana manusia menginterpretasikan dan bertindak terhadap informasi untuk membuat keputusan dalam berinvestasi. Jadi unsur sikap dan tindakan manusia merupakan faktor penentu dalam berinvestasi. Sehingga Behavioral finance, secara sederhana dapat didefinisikan sebagai aplikasi dari psikologi ke dalam disiplin ilmu keuangan untuk pengambilan keputusan keuangan di dalam rumah tangga, pasar dan organisasi. Usaha Kecil dan Menengah (UKM) termasuk dalam objek yang dapat diteliti dengan melihat perilaku manajer dalam pengambilan keputusan dan merupakan financial institution (Gumanti, 2009:8). Pengambilan keputusan yang

jmm.unram.ac.id 
digunakan dalam penelitian ini adalah keputusan investasi berupa keputusan penempatan dana untuk modal kerja pada UKM.

\subsection{Prospect Theory}

Prospect Theory adalah teori yang dikembangkan oleh Kahneman dan Tversky (1979) yang menggabungkan 2 (dua) disiplin yang berbeda yaitu ekonomi dan psikologi. Teori prospek berkaitan dengan ide bahwa manusia tidak selalu berperilaku secara rasional. Teori ini beranggapan bahwa ada bias yang melekat dan terus ada yang dimotivasi oleh faktor-faktor psikologi yang mempengaruhi pilihan orang dibawah kondisi ketidakpastian. Pada awalnya, seseorang membuat keputusan investasi berdasarkan pada estimasi dan prospek investasi. Namun seiring berjalannya waktu, faktor psikologis telah mempengaruhi seseorang dalam membuat keputusan investasinya. Bahkan para ahli menyatakan, bahwa faktor psikologis memiliki pengaruh yang besar bagi seseorang dalam mengambil keputusan (Pradhana, 2018). Pompian (2006) mengkategorikan bias psikologis dalam dua kategori yaitu Cognitive Bias dan Emotional Bias. Pada penelitian ini Cognitive Bias yang digunakan adalah Overconfidence, Cognitive Dissonance dan Illusion of Control, sedangkan Emotional Bias menggunakan Loss Aversion, Regret Aversion dan Status Quo.

\subsubsection{Overconfidence Bias}

Overconfidence atau sikap percaya diri berkaitan dengan seberapa besar prasangka atau perasaan tentang seberapa baik seseorang mengerti kemampuan mereka dan batas pengetahuan mereka sendiri. Hal ini didukung oleh pernyataan Shefrin (2007) yang dikutip sebagai berikut:

"overconfidence ia a bias that pertains to how well people understand their own abilities and the limits of their knowledge"

Penyebab dari overconfidence yaitu kepercayaan diri yang berlebihan bahwa informasi yang diperoleh mampu dimanfaatkan dengan baik karena memiliki kemampuan analisis yang akurat dan tepat, namun hal ini sebenarnya merupakan suatu ilusi pengetahuan dan kemampuan dikarenakan adanya beberapa alasan seperti pengetahuan yang kurang dan keterbatasan keahlian menginterpretasikan informasi (Baker and Nofsinger, 2002). Investor dengan overconfidence bias akan mengesampingkan informasi yang didapat karena dia terlalu percaya pada keyakinan sendiri. Investor percaya bahwa dengan melakukan investasi akan mendapatkan return yang tinggi dan risiko yang rendah, padahal hal ini tidak menjamin dan belum tentu terjadi demikian karena bisa berbeda dari perkiraan. Jenis bias ini mampu mempengaruhi pengambilan keputusan seseorang.

3.2.2. Cognitive Dissonance Bias

Cognitive dissonance bias adalah keadaan ketidakseimbangan yang terjadi ketika kognitif itu sendiri tidak sesuai. Suatu keadaan atau situasi ketika konflik muncul dari informasi yang diperoleh berbeda dengan pemahaman yang sudah diterima sebelumnya. Situasi dimana orang tidak nyaman dengan informasi baru yang ia dapatkan ini mampu menimbulkan keraguan pada pengertian awal yang dipahami (Pompian, 2006). Sehingga seseorang akan meyakinkan diri bahwa ia benar-benar sudah melakukan sesuatu yang lebih baik. Hal ini dimaksudkan untuk menghindari ketidaknyamanan mental yang berhubungan dengan pengertian awal mereka. Investor dengan kecenderungan bias tersebut dapat mempengaruhi pengambilan keputusan.

3.2.3. Illusion of Control Bias

Illusion of Control bias merupakan kecenderungan manusia percaya bahwa mereka dapat mengontrol atau paling tidak mempengaruhi hasil tetapi pada kenyataannya mereka tidak dapat (Pompian, 2006). Seseorang investor yang terkena bias ini biasanya akan merasa bahwa mereka seolah-olah mengontrol lebih atas lingkungan mereka melebihi mereka 
sebenarnya. Semakin sering atau aktif mereka mengambil keputusan sendiri maka akan semakin tinggi kejadian Illusion of Control

\subsubsection{Loss Aversion Bias}

Loss aversion bias merupakan perasaan yang sangat kuat dari dorongan hati untuk menghindari kerugian daripada mendapatkan keuntungan (Pompian, 2006). Dampak psikologis yang ditimbulkan oleh kerugian akan lebih besar daripada saat investor mengalami keuntungan. Investor akan lebih mengingat ketika mereka mengalami kerugian. Kecenderungan bias seperti ini dapat mempengaruhi keputusan investor dimana investor tersebut akan lebih berhati-hati ketika akan mengambil keputusan investasi karena investor merasa tidak ingin mengulangi kesalahan yang sama.

3.2.5. Regret Aversion Bias

Regret Aversion bias merupakan keputusan untuk bertindak menghindari kesalahan keputusan yang sama secara tegas karena ada perasaan takut (Pompian, 2006). Berusaha mencegah rasa sakit yang pernah dialami saat mengalami kerugian masa lalu. Investor yang menagalami bias ini cenderung merasa takut akan mengalami kerugian yang sama dan merasa salah.

3.2.6. Status Quo Bias

Pompian (2006), status quo bias menggambarkan bahwa mereka lebih suka tinggal pada kondisi yang sama atau menghindari perubahan. Perilaku ini bisa membuat investor lebih kompromi pada tujuan keuangan mereka. Investor akan cenderung mempertahankan kondisi yang ada untuk menghindari risiko yang diakibatkan sulitnya memprediksi masa depan. Investor dengan kecederungan bias ini dapat mempengaruhi pengambilan keputusan investasi.

\subsection{Keputusan Investasi}

Dalam manajemen keuangan ada tiga keputusan yang dilakukan oleh seorang manajer keuangan. Van Horne (2002:6) menyatakan tiga keputusan keuangan tersebut, yaitu:

1. Investment Decision,

2. Financing Decision, dan

\section{Dividend/Share Repurchase Decision}

Manajer keuangan dalam menentukan keputusan berapa banyak investasi yang akan dilakukan dan pada aktiva apa saja disebut investment decision. Van Horne (2002:6) menyatakan "The investment decision is the most important of the three decisions when it comes to the creation of value". Hal ini disebabkan investasi modal akan mendatangkan keuntungan yang diterima di masa yang akan datang. Berdasarkan hal tersebut, penelitian ini mengambil keputusan keuangan yaitu keputusan investasi berupa keputusan penempatan dana untuk modal kerja di UKM. Keputusan yang diambil oleh perusahaan dalam menentukan bagaimana memperoleh dana untuk membiayai investasi tersebut dinamakan financing decision. Financing Decision dapat dilakukan dengan pengambilan keputusan hutang. Atas dasar kedua keputusan ini, diharapkan perusahaan menghasilkan laba bersih yang tinggi untuk kemakmuran pemilik modal. Persoalan yang menyangkut pembagian laba bersih, baik yang akan diinvestasikan kembali dan yang akan dibagikan kepada para pemegang saham dalam bentuk dividen, dinamakan dengan Dividend/Share Repurchase Decision.

Keputusan investasi pada hakikatnya merupakan keputusan penempatan dana pada saat ini dengan harapan untuk memperoleh keuntungan dimasa mendatang (Halim, 2005). Beberapa investor atau pemodal memiliki alasan yang beragam untuk melakukan investasi, tergantung dari masing-masing individu. Menurut Tandelilin (2010), alasan orang melakukan investasi adalah untuk kehidupan yang lebih layak di masa depan, mengurangi tekanan inflasi, dan dorongan untuk menghemat pajak. 


\subsection{Kajian Empirik}

Penelitian yang berkaitan dengan cognitive bias dilakukan oleh Qadri and Shabbir (2014) yang menyatakan illusion of control dan overconfidence berpengaruh positif dan signifikan terhadap keputusan investasi. Hasil ini berbeda dengan penelitian Wulandari dan Iramani (2014) yang menyatakan bahwa overconfidence tidak berpengaruh terhadap pengambilan keputusan investasi. Sedangkan yang berkaitan dengan emotional bias yaitu Khilar and Singh (2020) yang menyatakan emotional bias berpengaruh terhadap keputusan investasi. Demikian juga dengan penelitian Duxbury (2015) yang menyatakan emotional bias berpengaruh poitif dan signifikan terhadap pengambilan keputusan investasi. Hasil yang berbeda ditunjukkan oleh Kartini dan Nuris (2015) yang menyatakan bahwa emotional bias berpengaruh negatif terhadap pengambilan keputusan investasi.

Beberapa penelitian behavioral finance selama ini lebih diarahkan untuk menganalisis kaitan faktor psikologis tertentu dengan keputusan keuangan, yaitu Persepsi dan Faktor Psikologis dalam Pengambilan Keputusan Hutang (Supramono dan Putlia, 2010), yang menyatakan aspek psikologis turut berperan dalam keputusan pengambilan hutang, Penelitian dilakukan oleh Mien dan Thao (2015) yang dilakukan pada masyarakat Vietnam menyatakan bahwa sikap keuangan dan pengetahuan keuangan memiliki hubungan yang signifikan positif dengan perilaku manajemen keuangan. Amanah, dkk. (2016) menyatakan financial knowledge dan financial attitude berpengaruh terhadap personal financial management behavior. Wiharno (2018) menyatakan variabel financial knowledge, financial behaviour dan financial attitude secara parsial berpengaruh positif signifikan terhadap manajemen keuangan personal. Humairo (2018) terdapat pengaruh positif Pengetahuan Keuangan terhadap Perilaku Manajemen Keuangan pada pelaku UMKM Sentra Kerajinan Batik Kab.Bantul, (2) terdapat pengaruh positif Sikap Keuangan terhadap Perilaku Manajemen Keuangan pada pelaku UMKM Sentra Kerajinan Batik Kab.Bantul, (3) terdapat pengaruh positif Kepribadian terhadap Perilaku Manajemen Keuangan pada pelaku UMKM Sentra Kerajinan Batik Kab.Bantul. Lianto dan Elizabeth (2017) menyatakan pengetahuan keuangan dan sikap keuangan tidak berpengaruh signifikan terhadap financial behavior. Herdjiono dan Damanik (2016) menyatakan pengetahuan keuangan tidak berpengaruh terhadap financial management behavior. Hidayati dkk. (2019) menyatakan Financial Attitudes dan Financial knowledge berpengaruh positif dan signifikan terhadap Keputusan Keuangan artinya semakin baik Financial Attitude dan Financial Knowledge manajer sekaligus pemilik UKM maka semakin berani dalam pengambilan keputusan Keuangan.

Penelitian yang sudah dilakukan berkaitan dengan behavioral finance yang ada di UKM yaitu Mental Accounting Dan Dampaknya Terhadap Kinerja Perusahaan Melalui Penempatan Modal Kerja Pada Usaha Kecil Dan Menengah Di Pulau Lombok (Hidayati, Wahyulina, Wardani dan Negara (2015) menyatakan mental accounting berpengaruh signifikan terhadap kinerja perusahaan melalui keputusan investasi penempatan dana untuk modal kerja. Hidayati, Wahyulina dan Widiana (2016) dalam penelitian Pengaruh Risk Attitudes Terhadap Kinerja Perusahaan Melalui Keputusan Penempatan Modal Kerja menyatakan risk attitudes berpengaruh signifikan terhadap kinerja perusahaan melalui keputusan investasi penempatan dana untuk modal kerja. Hidayati, Wahyulina, Suryani, (2017) dalam penelitian yang berjudul Behavioral Finance dan Pengaruhnya terhadap Pengambilan Keputusan Hutang menyatakan 1) Overconfidence berpengaruh tidak signifikan terhadap pengambilan keputusan hutang, 2) Illusion of Control berpengaruh signifikan terhadap pengambilan keputusan hutang dan 3) Avaibility berpengaruh tidak signifikan terhadap pengambilan keputusan hutang. Hidayati, Wahyulina dan Suryani (2018) dalam penelitian yang berjudul Pengaruh Behavioral Finance Terhadap Kinerja Perusahaan Melalui Pengambilan Keputusan Hutang (Studi Pada Usaha Kecil Dan Menengah (UKM) Di Pulau Lombok) menyatakan 1) Overconfidence berpengaruh 
signifikan terhadap pengambilan keputusan hutang, 2) Illusion of Control berpengaruh tidak signifikan terhadap pengambilan keputusan hutang, 3) Avaibility berpengaruh signifikan terhadap pengambilan keputusan hutang, 4) Pengambilan keputusan hutang berpengaruh tidak signifikan terhadap kinerja Perusahaan, dan 5) Pengambilan keputusan hutang bukan variabel intervening Overconfidence, Illusion of Control dan Avaibility terhadap Kinerja Perusahaan

\subsection{Kerangka Konseptual}

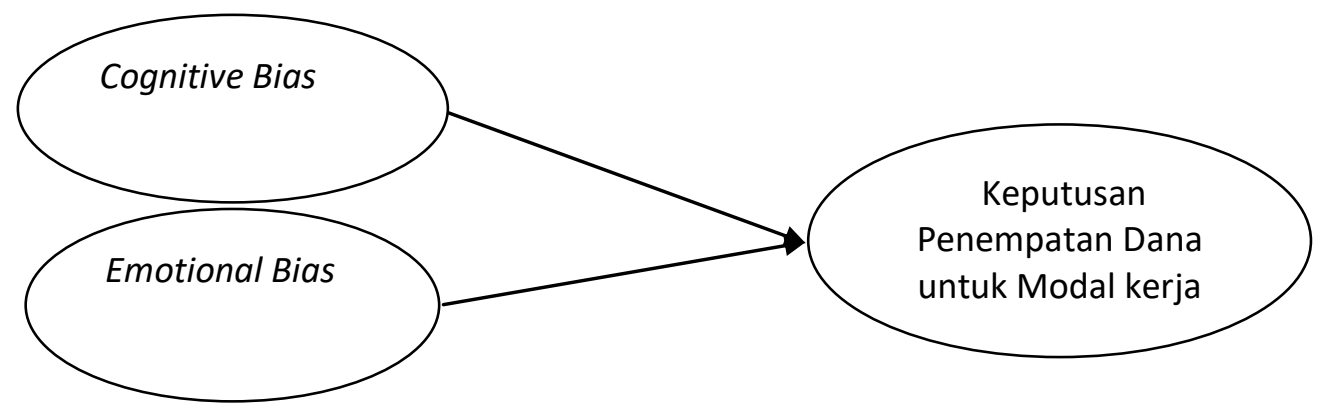

\section{HASIL DAN PEMBAHASAN}

\subsection{Karakteristik Responden}

Karakteristik responden berdasarkan usia menunjukkan sebagian besar responden berusia lebih dari 37 tahun sampai dengan 54 tahun. Responden yang berusia lebih dari 54 tahun lebih sebanyak 18 persen dan lebih dari 29 sampai dengan 37 tahun sebanyak 15 persen. Ditinjau dari usianya, sebagian manajer UKM di Pulau Lombok berada pada usia produktif. Artinya, para manajer UKM tersebut mempunyai kemampuan fisik untuk bekerja dan memiliki potensi berpikir dan bertindak secara efektif sehingga diharapkan dapat mengambil keputusan.

Karakteristik responden berdasarkan jenis kelamin menunjukkan 76 persen laki-laki dan sisanya perempuan. Artinya pengambil keputusan pada UKM industri gerabah di Pulau Lombok sebagian besar berjenis kelamin laki-laki, sehinggga bisa dikatakan keberlangsungan usaha banyak didominasi kaum laki-laki selaku manajer sekaligus pemilik perusahaan. Hal ini terjadi karena pengelola UKM adalah kepala rumah tangga.

Karakteristik responden dilihat dari tingkat pendidikan menunjukkan sebagian besar tamatan SMA, yaitu sebesar 44 persen, perguruan tinggi sebesar 38 persen, SD sebesar 9 persen dan SMP sebesar 9 persen. Tingkatan pendidikan manajer UKM akan berpengaruh terhadap pengambilan keputusan dalam pengelolaan usahanya.

Karakteristik responden berdasarkan jumlah karyawan yang dimiliki menunjukkan bahwa sebagian besar responden, yaitu 91,4 persen, memiliki karyawan tetap dari 1 sampai dengan 10 orang. Jika ada pesanan dalam jumlah yang relatif besar biasanya pemilik UKM akan menambah jumlah karyawannya. Dengan kata lain, perusahaan akan melakukan penambahan jumlah karyawan sewaktu-waktu apabila dibutuhkan.

Karakteristik responden dilihat dari lama usahanya menunjukkan 61 persen lebih dari 15 tahun, lebih dari 5 sampai 10 tahun 18 persen, lebih besar dari 10 sampai dengan 15 tahun sebanyak 21 persen. Kondisi ini mencerminkan sebagian besar responden sudah melangsungkan usahanya lebih dari 15 tahun. Hal ini menunjukkan manajer sekaligus pemilik UKM sudah banyak pengalaman dalam pengelolaaan usaha yang dimiliki. 


\subsection{Deskripsi Variabel Penelitian}

Analisis deskripsi variabel bertujuan untuk menginterpretasikan makna masingmasing variabel penelitian, indikator variabel dan item pernyataan penelitian berdasarkan distribusi frekuensi, persentase dan rerata (mean) jawaban responden. Berdasarkan skala pengukuran data yang digunakan (Likert), rentang skala pernyataan responden di mulai dari satu sampai lima. Variabel-variabel yang dianalisis dalam penelitian ini terdiri atas :

Variabel-variabel yang dianalisis dalam penelitian ini terdiri atas : Cognitive bias (X1), Emotional Bias (X2) dan Pengambilan Keputusan Keuangan (Y1).Untuk menggambarkan variabel-variabel tersebut digunakan metode statistik deskriptif, sedangkan untuk menguji dan menganalisis pengaruh antar variabel penelitian digunakan GSCA. Deskripsi setiap indikator dan variabel dapat diuraikan sebagai berikut.

\subsubsection{Variabel Cognitive Bias (X1)}

Variabel Cognitive Bias (X1) memiliki 3 indikator, yaitu: Overconfidence, Cognitive Dissonance Bias dan Illusion of Control Bias. Setiap indikator memiliki dua item pernyataan.

Tabel 4.1.

Deskrispsi Variabel Cognitive Bias (X1)

\begin{tabular}{|c|c|c|c|c|c|c|c|c|c|c|c|c|c|}
\hline \multirow{3}{*}{$\begin{array}{l}\text { Var } \\
\text { ia } \\
\text { bel }\end{array}$} & \multirow{3}{*}{$\begin{array}{c}\text { Per } \\
\text { nya } \\
\text { taa } \\
n\end{array}$} & \multicolumn{10}{|c|}{ Jawaban Responden } & \multirow{3}{*}{$\begin{array}{c}\text { Rera } \\
\text { ta } \\
\text { (Mea } \\
\text { n) } \\
\text { Item }\end{array}$} & \multirow{3}{*}{$\begin{array}{l}\text { Rera } \\
\text { ta } \\
\text { (Me } \\
\text { an) } \\
\text { Varia } \\
\text { bel }\end{array}$} \\
\hline & & \multicolumn{2}{|c|}{$\begin{array}{c}\text { Sangat } \\
\text { Tidak } \\
\text { Setuju } \\
\text { (STS) }\end{array}$} & \multicolumn{2}{|c|}{$\begin{array}{c}\text { Tidak } \\
\text { Setuju (TS) }\end{array}$} & \multicolumn{2}{|c|}{ Netral $(\mathrm{N})$} & \multicolumn{2}{|c|}{$\begin{array}{l}\text { Setuju } \\
\text { (S) }\end{array}$} & \multicolumn{2}{|c|}{$\begin{array}{l}\text { Sangat } \\
\text { Setuju } \\
\text { (SS) }\end{array}$} & & \\
\hline & & $\mathrm{F}$ & $\%$ & $\mathrm{~F}$ & $\%$ & $F$ & $\%$ & $\mathrm{~F}$ & $\%$ & $\mathrm{~F}$ & $\%$ & & \\
\hline \multirow[t]{6}{*}{$\mathrm{X} 1$} & $\mathrm{X} 11$ & 0 & 0,0 & 7 & 20,6 & 1 & 2,9 & 18 & 52,9 & 8 & 23,5 & 3,79 & \multirow{6}{*}{3,56} \\
\hline & $\mathrm{X} 12$ & 0 & 0,0 & 7 & 20,6 & 1 & 2,9 & 12 & 35,3 & 14 & 41,2 & 3,97 & \\
\hline & $\mathrm{X} 13$ & 0 & 0,0 & 7 & 20,6 & 0 & 0 & 18 & 52,9 & 9 & 26,5 & 3,85 & \\
\hline & X14 & 3 & 8,8 & 14 & 41,2 & 6 & 17,6 & 10 & 29,4 & 1 & 2.9 & 2,67 & \\
\hline & X15 & 0 & 0,0 & 10 & 29,4 & 4 & 11,8 & 15 & 44,1 & 5 & 14,7 & 3,44 & \\
\hline & $\mathrm{X} 16$ & 0 & 0,0 & 7 & 20,6 & 4 & 11,8 & 18 & 52,9 & 5 & 14,7 & 3,62 & \\
\hline
\end{tabular}

Berdasarkan tabel 4.1, semua item pernyataan mempunyai skor dibawah 4, artinya responden tidak mempunyai sikap yang menunjukkan overconfidence, cognitive dissonance bias dan illusion of control bias. Demikian pula skor variabel yang menunjukkan skor 3,56, berarti responden tidak menunjukkan sikap yang mencerminkan cognitive bias.

\subsubsection{Variabel Emotional Bias (X2)}

Variabel ini memiliki 3 indikator, yaitu:. Loss Aversion Bias, Regret Aversion Bias dan Status $Q u$. Bias. Setiap indikator memiliki dua item pernyataan 
Tabel 4.2.

Deskrispsi Variabel Emotional Bias (X2)

\begin{tabular}{|c|c|c|c|c|c|c|c|c|c|c|c|c|c|}
\hline \multirow{3}{*}{$\begin{array}{l}\text { Var } \\
\text { ia } \\
\text { bel }\end{array}$} & \multirow{3}{*}{$\begin{array}{c}\text { Per } \\
\text { nya } \\
\text { taa } \\
\mathrm{n}\end{array}$} & \multicolumn{10}{|c|}{ Jawaban Responden } & \multirow{3}{*}{$\begin{array}{c}\text { Rera } \\
\text { ta } \\
(\text { Mea } \\
\text { n) } \\
\text { Item }\end{array}$} & \multirow{3}{*}{$\begin{array}{l}\text { Rera } \\
\text { ta } \\
\text { (Me } \\
\text { an) } \\
\text { Varia } \\
\text { bel }\end{array}$} \\
\hline & & \multicolumn{2}{|c|}{$\begin{array}{c}\text { Sangat } \\
\text { Tidak } \\
\text { Setuju } \\
\text { (STS) }\end{array}$} & \multicolumn{2}{|c|}{$\begin{array}{c}\text { Tidak } \\
\text { Setuju (TS) }\end{array}$} & \multicolumn{2}{|c|}{ Netral (N) } & \multicolumn{2}{|c|}{$\begin{array}{l}\text { Setuju } \\
\text { (S) }\end{array}$} & \multicolumn{2}{|c|}{$\begin{array}{l}\text { Sangat } \\
\text { Setuju } \\
\text { (SS) }\end{array}$} & & \\
\hline & & $\mathrm{F}$ & $\%$ & F & $\%$ & F & $\%$ & $\mathrm{~F}$ & $\%$ & $\mathrm{~F}$ & $\%$ & & \\
\hline \multirow[t]{6}{*}{$\mathrm{X} 2$} & $\mathrm{X} 21$ & 0 & 0,0 & 5 & 14,7 & 5 & 14,7 & 17 & 50 & 7 & 20,6 & 3,76 & \multirow{6}{*}{3,7} \\
\hline & $\mathrm{X} 22$ & 0 & 0,0 & 5 & 14,7 & 11 & 32,4 & 13 & 38,2 & 5 & 14,7 & 3,53 & \\
\hline & $\mathrm{X} 23$ & 0 & 0,0 & 7 & 20,6 & 3 & 8,8 & 18 & 52,9 & 6 & 17,6 & 3,68 & \\
\hline & X24 & 0 & 0,0 & 5 & 14,7 & 1 & 2,9 & 16 & 47,1 & 12 & 35,3 & 4,03 & \\
\hline & X25 & 0 & 0,0 & 12 & 35,3 & 9 & 26,5 & 4 & 11,8 & 9 & 26,5 & 3,29 & \\
\hline & X26 & 0 & 0,0 & 6 & 17,6 & 2 & 5,9 & 15 & 44,1 & 11 & 32,4 & 3,91 & \\
\hline
\end{tabular}

Berdasarkan tabel 4.2, item pernyataan "saya lebih menghindari kerugian yang sama" yang mempunyai skor diatas 4, artinya responden mempunyai sikap lebih meghindari kerugian yang sama dalam menempatkan dananya untuk modal kerja. Secara keseluruhan atau rerata variabel ini menunjukkan responden tidak mempunyai sikap yang mencerminkan Emotional Bias. Hal ini ditunjukkan oleh skor yang diperoleh masih dibawah 4

\subsubsection{Variabel Keputusan Penempatan Dana untuk Modal Kerja (Y1)}

Variabel terdiri dari 3 indikator dan 9 pernyataan, yaitu: Efficiency of Cash Management/ECM (Y1.1) dengan 3 pernyataan, Efficiency of Receivables Management/ERM (Y1.2) dengan 3 pernyataan dan Efficiency of Inventory Management/EIM (Y1.3) dengan 3 pernyataan.

Tabel 4.3.

Deskripsi Variabel Keputusan Penempatan Dana untuk Modal kerja (Y1)

\begin{tabular}{|c|c|c|c|c|c|c|c|c|c|c|c|c|c|}
\hline \multirow{3}{*}{$\begin{array}{c}\text { Varia } \\
\text { bel }\end{array}$} & \multirow{3}{*}{$\begin{array}{l}\text { Per } \\
\text { nya } \\
\text { taan }\end{array}$} & \multicolumn{10}{|c|}{ Jawaban Responden } & \multirow{3}{*}{$\begin{array}{c}\text { Rera } \\
\text { ta } \\
\text { (Mean) } \\
\text { Item }\end{array}$} & \multirow{3}{*}{$\begin{array}{l}\text { Rera } \\
\text { ta (Me } \\
\text { an) } \\
\text { Indi } \\
\text { ka } \\
\text { tor }\end{array}$} \\
\hline & & \multicolumn{2}{|c|}{$\begin{array}{c}\text { Sangat } \\
\text { Tidak } \\
\text { Setuju } \\
\text { (STS) }\end{array}$} & \multicolumn{2}{|c|}{$\begin{array}{c}\text { Tidak } \\
\text { Setuju (TS) }\end{array}$} & \multicolumn{2}{|c|}{ Netral (N) } & \multicolumn{2}{|c|}{ Setuju (S) } & \multicolumn{2}{|c|}{$\begin{array}{c}\text { Sangat } \\
\text { Setuju } \\
\text { (SS) }\end{array}$} & & \\
\hline & & $\mathrm{F}$ & $\%$ & $\mathrm{~F}$ & $\%$ & $\mathrm{~F}$ & $\%$ & $\mathrm{~F}$ & $\%$ & $\mathrm{~F}$ & $\%$ & & \\
\hline \multirow[t]{9}{*}{ Y1 } & Y11 & 0 & 0 & 6 & 17,6 & 4 & 11,8 & 18 & 52,9 & 6 & 17,6 & 3,7 & \multirow{9}{*}{3,75} \\
\hline & Y12 & 0 & 0,0 & 7 & 20,6 & 5 & 14,7 & 16 & 47,1 & 6 & 17,6 & 3,62 & \\
\hline & Y13 & 0 & 0,0 & 6 & 17,6 & 3 & 8,8 & 18 & 52,9 & 7 & 20,6 & 3,76 & \\
\hline & Y14 & 0 & 0,0 & 8 & 23,5 & 8 & 23,5 & 14 & 41,2 & 4 & 11,8 & 3,41 & \\
\hline & Y15 & 0 & 0,0 & 6 & 17,6 & 1 & 2,9 & 19 & 55,9 & 8 & 23,5 & 3,85 & \\
\hline & Y16 & 0 & 0,0 & 7 & 20,6 & 3 & 8,8 & 19 & 55,9 & 5 & 14,7 & 3,65 & \\
\hline & Y17 & 0 & 0,0 & 6 & 17,6 & 3 & 8,8 & 13 & 38,2 & 12 & 35,3 & 3,91 & \\
\hline & Y18 & 0 & 0,0 & 6 & 17,6 & 1 & 2,9 & 16 & 47,1 & 11 & 32,4 & 3,94 & \\
\hline & Y19 & 0 & 0,0 & 6 & 17,6 & 1 & 2,9 & 16 & 47,1 & 11 & 32,4 & 3,94 & \\
\hline
\end{tabular}


Berdasarkan tabel 4.3, semua item pernyataaan dari variabel penempatan dana untuk modal kerja berada dibawah skor 4, artinya responden tidak efisien dalam keputuan penempatan dana untuk modal kerja dilihat dari efisiensi manajemen kas, piutang dan persediaan.

\subsection{Pengujian Validitas dan Realibilitas}

4.3.1. Uji Validitas dan Realibilitas Cognitive Bias (X1)

Hasil uji validitas dan reliabilitas terhadap instrumen penelitian untuk variabel cognitive bias (X1) disajikan pada Tabel 4.5.

Tabel 4.4.

Hasil Uji Validitas dan Reliabilitas Cognitive Bias (X1)

\begin{tabular}{|c|c|c|c|c|}
\hline \multirow{2}{*}{ Pernyataan } & \multicolumn{3}{|c|}{ Cognitive Bias } \\
\cline { 2 - 3 } & \multicolumn{2}{|c|}{ Validitas } & \multicolumn{2}{c|}{ Reliabilitas } \\
\cline { 2 - 3 } & Pearson Correlation & Keterangan & $\begin{array}{c}\text { Alpha } \\
\text { Cronbach }\end{array}$ & Keterangan \\
\hline X11 & 0,900 & Valid & \multirow{2}{*}{0,920} & \multirow{2}{*}{ Reliabel } \\
\hline X12 & 0,889 & Valid & \\
\hline X13 & 0,865 & Valid & & \\
\hline X14 & 0,599 & Valid & & \\
\hline X15 & 0,894 & Valid & & \\
\hline X16 & 0,940 & Valid & & \\
\hline
\end{tabular}

Hasil uji validitas Cognitive Bias menunjukkan semua pernyataan sudah valid karena memiliki nilai korelasi pearson lebih besar dari 0,3. Nilai Alpha Cronbach lebih besar dari 0,6 yang berarti syarat reliabilitas terpenuhi.

\subsubsection{Uji Validitas dan Reliabilitas Emotional Bias (X2)}

Hasil uji validitas dan reliabilitas terhadap instrumen penelitian untuk Variabel Emotional Bias disajikan pada Tabel 4.6.

Tabel 4.5.

Hasil Uji Validitas dan Reliabilitas Emotional Bias (X2)

\begin{tabular}{|c|c|c|c|c|}
\hline \multirow{2}{*}{ Pernyataan } & \multicolumn{3}{|c|}{ Emotional Bias } \\
\cline { 2 - 3 } & \multicolumn{2}{|c|}{ Validitas } & \multicolumn{2}{c|}{ Reliabilitas } \\
\cline { 2 - 3 } & Pearson Correlation & Keterangan & $\begin{array}{c}\text { Alpha } \\
\text { Cronbach }\end{array}$ & Keterangan \\
\hline X2.1 & 0,759 & Valid & \multirow{2}{*}{0,904} & \multirow{2}{*}{ Reliabel } \\
\hline X2.2 & 0,881 & Valid & \\
\hline X2.3 & 0,830 & Valid & \\
\hline X2.4 & 0,935 & Valid & \\
\hline X2.5 & 0,743 & Valid & \\
\hline X2.6 & 0,822 & Valid & & \\
\hline
\end{tabular}

Hasil uji validitas menunjukkan semua pernyataan sudah valid karena memiliki nilai korelasi pearson lebih besar dari 0,3. Nilai Alpha Cronbach lebih besar dari 0,6 yang berarti syarat reliabilitas terpenuhi. 


\subsubsection{Uji Validitas dan Reliabilitas Keputusan Penempatan Dana utuk Modal Kerja (Y1)}

Tabel 4.6

Hasil Uji Validitas dan Reliabilitas Keputusan Penempatan Dana untuk Modal Kerja (Y1)

\begin{tabular}{|c|c|c|c|c|}
\hline \multirow{2}{*}{ Pernyataan } & \multicolumn{3}{|c|}{ Keputusan Penempatan Dana untuk Modal Kerja } \\
\cline { 2 - 3 } & \multicolumn{2}{|c|}{ Validitas } & \multicolumn{2}{c|}{ Reliabilitas } \\
\cline { 2 - 3 } & Pearson Correlation & Keterangan & $\begin{array}{c}\text { Alpha } \\
\text { Cronbach }\end{array}$ & Keterangan \\
\hline Y11 & 0,898 & Valid & \multirow{2}{*}{0,972} & \multirow{2}{*}{ Reliabel } \\
\hline Y12 & 0,881 & Valid & \\
\hline Y13 & 0,933 & Valid & & \\
\hline Y14 & 0,796 & Valid & & \\
\hline Y15 & 0,934 & Valid & & \\
\hline Y16 & 0,861 & Valid & & \\
\hline Y17 & 0,952 & Valid & & \\
\hline Y18 & 0,947 & Valid & & \\
\hline Y19 & 0,937 & Valid & & \\
\hline
\end{tabular}

Hasil uji validitas menunjukkan semua pernyataan sudah valid karena memiliki nilai korelasi pearson lebih besar dari 0,3. Nilai Alpha Cronbach lebih besar dari 0,6 yang berarti syarat reliabilitas terpenuhi.

\subsection{Pengujian Asumsi Linearitas}

Sebelum mengadakan pengujian pengaruh variabel eksogen terhadap variabel endogen melalui generalized structured component analysis (GSCA) terlebih dahulu mengadakan pengujian asumsi linieritas. Pengujian asumsi linieritas dimaksudkan untuk melihat apakah hubungan antara variabel eksogen terhadap variabel endogen linier atau tidak. Jika hubungan tersebut linier, maka pengujian dapat ditindaklanjuti. Adanya hubungan linier variabel eksogen dengan variabel endogen menunjukkan hubungan yang searah.

Analisis melalui pemodelan berdasarkan hasil uji asumsi linieritas penggunaan GSCA menunjukkan bahwa hubungan variabel eksogen dengan variabel endogen adalah signifikan. Dengan menggunakan test of linearity, dapat disimpulkan bahwa semua variabel linier dengan tingkat signifikansi Deviation from linearity lebih besar dari 0,05 dapat dikatakan model bisa untuk dilanjutkan. Hasil pengujian linieritas hubungan antara variabel disajikan secara ringkas pada Tabel 4.7.

Tabel 4.7

Hasil Pengujian Asumsi Linearitas

\begin{tabular}{|l|c|c|c|}
\hline \multicolumn{2}{|c|}{ Hubungan Antar Variabel } & $\begin{array}{c}\text { Signifikansi } \\
\text { Deviation from } \\
\text { linearity }\end{array}$ & Keterangan \\
\hline $\mathrm{X} 1$ & $\mathrm{Y} 1$ & 0,929 & Linier \\
\hline $\mathrm{X} 2$ & $\mathrm{Y} 1$ & 0,514 & Linier \\
\hline
\end{tabular}

Pada tabel 4.7 terlihat bahwa hubungan variabel eksogen dengan variabel endogen semuanya linier dan signifikan dengan tingkat $>0,05$, sehingga dapat dikatakan bahwa asumsi linieritas terpenuhi.

\subsection{Hasil Analisis Generalized Structured Component Analysis}

Metode analisis data yang digunakan dalam penelitian ini adalah Generalized Structured Component Analysis (GSCA). GSCA adalah model persamaan struktural (SEM) yang berbasis 
komponen atau varian (variance), Dalam penelitian ini, pengujian model struktural dan hipotesis penelitian dengan melihat nilai koefisien jalur dari variabel eksogen ke endogen dan melihat nilai signifikansi. Pengujian model struktural dalam GSCA dilakukan melalui resampling bootstrap. Evaluasi model struktural dan hipotesis bertujuan untuk mengetahui seberapa besar informasi yang dapat dijelaskan oleh model struktural (hubungan antara variabel laten). Lebih jelasnya uraian analisis dan evaluasi model pada GSCA penelitian ini sebagai berikut:

\subsubsection{Measure of Fit Structural Model}

Measure of Fit Structural Model diukur menggunakan FIT, yaitu setara dengan $\mathrm{R}^{2}$ pada analisis regresi atau koefisien determinasi total pada analisis jalur atau $\mathrm{Q}^{2}$ pada PLS, FIT menunjukkan varian total dari semua variabel yang dapat dijelaskan oleh model struktural. Nilai FIT berkisar dari 0 sampai 1, semakin besar nilai ini, semakin besar proporsi varian variabel yang dapat dijelaskan oleh model. Jika nilai FIT $=1$ berarti model secara sempurna dapat menjelaskan fenomena yang diselidiki. AFIT (Adjusted FIT) serupa dengan $\mathrm{R}^{2}$ adjusted pada analisis regresi. AFIT dapat digunakan untuk perbandingan model. Model dengan AFIT nilai terbesar dapat dipilih antara model yang lebih baik (Solimun, 2012).

Tabel 4.8.

Hasil Pengujian Measure of fit Structural Model

\begin{tabular}{|c|c|c|c|}
\hline FIT & AFIT & GFI & SRMR \\
\hline 0.699 & 0.284 & 0.994 & 0.053 \\
\hline
\end{tabular}

Hasil pengujian Measure of Fit Structural Model berdasarkan Tabel 4.9. memperlihatkan bahwa proporsi varian variabel yang dapat dijelaskan oleh model adalah sebesar 28,4 persen atau keragaman Cognitive Bias, Emotional Bias dan Keputusan Penempatan Dana untuk Modal kerja dapat dijelaskan oleh model adalah sebesar 28,4 persen. Sedangkan 71,6 persen dijelaskan oleh faktor-faktor lain, seperti: lingkungan pergaulan dan cara bersosialisasi, faktor kebiasaan, locus of control (Joo, et al., 2003). Goodness Fit of Index (GFI) sebesar 0,994 mengindikasikan bahwa model fit (layak) karena mendekati nilai 1 (satu), demikian juga untuk nilai SRMR (Standardized root mean square residual) mendekati 0 mengindikasikan model yang dihasilkan layak.

\subsubsection{Measurement Model Masing-masing Variabel}

Measurement Model diukur berdasarkan nilai loading factor (standardize coefficient) pada setiap indikator ke variabel laten. Nilai loading factor menunjukkan bobot setiap faktor sebagai pengukur masing-masing variabel. Indikator dengan loading factor terbesar menunjukkan bahwa indikator tersebut sebagai pengukur variabel dominan (terkuat).

Variabel Cognitive Bias (X1) memiliki 3 indikator, yaitu: Overconfidence, Cognitive Dissonance Bias dan Illusion of Control Bias. Setiap indikator memiliki dua item pernyataan.Variabel ini mempunyai indikator yang bersifat reflektif. Nilai Loading Estimate untuk setiap indikator dan Alpha adalah sebagai berikut. 
Tabel 4.9.

Estimates of Loadings: Variabel Cognitive Bias

Alpha: 0,922

\begin{tabular}{|c|c|c|c|c|}
\hline & Estimate & SE & \multicolumn{2}{|c|}{$95 \%$ CI } \\
\hline $\mathrm{X} 1$ & \multicolumn{3}{|l|}{} \\
\hline $\mathrm{X} 1.1$ & 0.908 & 0.033 & 0.824 & 0.958 \\
\hline $\mathrm{X} 1.2$ & 0.903 & 0.042 & 0.791 & 0.956 \\
\hline $\mathrm{X} 1.3$ & 0.889 & 0.041 & 0.794 & 0.948 \\
\hline $\mathrm{X} 1.4$ & 0.539 & 0.115 & 0.313 & 0.746 \\
\hline $\mathrm{X} 1.5$ & 0.885 & 0.039 & 0.79 & 0.953 \\
\hline $\mathrm{X} 1.6$ & 0.949 & 0.02 & 0.908 & 0.978 \\
\hline
\end{tabular}

Hasil komputasi model pengukuran variabel cognitive bias pada tabel 4.10 menunjukkan bahwa ketiga indikator valid digunakan dalam merefleksikan pengukuran variabel cognitive bias. Dibuktikan dengan nilai loading estimate ketiga indikator berada diantara nilai 95\%CI. Mencerminkan bahwa korelasi di antara semua indikator variabel positif dan signifikan dalam merefleksikan variabel laten. Hasil analisis data dengan metode GSCA menunjukkan nilai alpha yang diperoleh sebesar 0,922, yang artinya variabel ini memiliki konsistensi reliabilitas internal yang baik karena lebih besar dari 0,6 .

Berdasarkan hasil analisis data, jika dilihat dari nilai loading estimate yang diperoleh oleh masing-masing indikator, indikator illusion of control bias dengan item pernyataan "Saya yakin dapat melakukan amtisipasi jika terjadi masalah ditengah jalan" paling dominan dalam merefleksikan variabel cognitive bias.

Hasil pengujian menunjukkan cognitive bias manajer sekaligus pemilik UKM paling direfleksikan oleh illusion of control bias dengan pernyataan "Saya yakin dapat melakukan antisipasi jika terjadi masalah ditengah jalan" dengan nilai rerata 3,62. Artinya belum semua manajer sekaligus pemilik UKM yakin dapat melakukan antispasi jika terjadi masalah ditengah jalan. Hal ini bisa dibuktikan dengan adanya pandemi covid 19 kinerja UKM cenderung menurun. Berdasarkan hasil survei LIPI tahun 2020, pandemi covid-19 menyebabkan profit usaha menurun secara signifikan akibat biaya produksi tetap atau bahkan meningkat sementara penjualan menurun. Biaya usaha yang mengalami peningkatan selama pandemi yaitu bahan baku, transportasi, tenaga kerja, dan biaya lain-lain ((http:/ /lipi.go.id/berita/survei-kinerja-umkm-di-masa-pandemi-covid19/22071).

Tabel 4.10.

Estimates of Loadings: Variabel Emotional Bias

Alpha $=0,909$

\begin{tabular}{|c|c|c|c|c|}
\hline & Estimate & SE & \multicolumn{2}{|c|}{$95 \% \mathrm{CI}$} \\
\hline \multicolumn{5}{|l|}{$\mathrm{X} 2$} \\
\hline $\mathrm{X} 2.1$ & 0.782 & 0.072 & 0.651 & 0.908 \\
\hline $\mathrm{X} 2.2$ & 0.891 & 0.029 & 0.826 & 0.942 \\
\hline$X 2.3$ & 0.829 & 0.061 & 0.713 & 0.943 \\
\hline X2.4 & 0.942 & 0.029 & 0.853 & 0.979 \\
\hline$X 2.5$ & 0.71 & 0.059 & 0.567 & 0.827 \\
\hline$X 2.6$ & 0.815 & 0.108 & 0.549 & 0.951 \\
\hline
\end{tabular}


Hasil komputasi model pengukuran variabel emotional bias pada tabel 4.11 menunjukkan bahwa ketiga indikator valid digunakan dalam merefleksikan pengukuran variabel emotional bias. Dibuktikan dengan nilai loading estimate ketiga indikator berada diantara nilai $95 \%$ CI. Mencerminkan bahwa korelasi di antara semua indikator variabel positif dan signifikan dalam merefleksikan variabel laten. Hasil Analisis data dengan metode GSCA menunjukkan nilai alpha yang diperoleh sebesar 0,909, yang artinya variabel ini memiliki konsistensi reliabilitas internal yang baik karena lebih besar dari 0,6 .

Berdasarkan hasil analisis data, jika dilihat dari nilai loading estimate yang diperoleh oleh masing-masing indikator, indikator regret aversion bias dengan item pernyataan "Saya lebih menghindari kerugian yang sama" paling dominan dalam merefleksikan variabel emotional bias.

Hasil pengujian menunjukkan emotional bias manajer sekaligus pemilik UKM paling direfleksikan oleh regret aversion bias dengan pernyataan "Saya lebih menghindari kerugian yang sama" dengan nilai rerata 4,03. Artinya manajer sekaligus pemilik UKM sudah bisa menghindar dari kerugian yang sama, yang sudah terjadi sebelumnya.

Tabel 4.11.

Estimates of Loadings: Variabel Keputusan Penempatan Dana untuk Modal kerja Alpha $=0,972$

\begin{tabular}{|c|c|c|c|c|}
\hline & Estimate & SE & \multicolumn{2}{|c|}{$95 \%$ CI } \\
\hline Y1 & & 0.03 & 0.841 & 0.951 \\
\hline Y1.1 & 0.909 & 0.046 & 0.776 & 0.952 \\
\hline Y1.2 & 0.881 & 0.021 & 0.896 & 0.967 \\
\hline Y1.3 & 0.939 & 0.084 & 0.599 & 0.894 \\
\hline Y1.4 & 0.785 & 0.035 & 0.819 & 0.966 \\
\hline Y1.5 & 0.932 & 0.093 & 0.624 & 0.963 \\
\hline Y1.6 & 0.852 & 0.015 & 0.915 & 0.976 \\
\hline Y1.7 & 0.952 & 0.019 & 0.906 & 0.973 \\
\hline Y1.8 & 0.948 & 0.024 & 0.879 & 0.971 \\
\hline Y1.9 & 0.939 & & \\
\hline
\end{tabular}

Hasil komputasi model pengukuran variabel Keputusan Keuangan pada tabel 4.12 menunjukkan bahwa ketiga indikator valid digunakan dalam merefleksikan pengukuran variabel Keputusan Keuangan. Dibuktikan dengan nilai loading estimate kedua indikator berada diantara nilai 95\%CI. Mencerminkan bahwa korelasi di antara semua indikator variabel signifikan dalam merefleksikan variabel laten. Hasil analisis data dengan metode GSCA menunjukkan nilai alpha yang diperoleh sebesar 0,972, yang artinya variabel ini memiliki konsistensi reliabilitas internal yang baik karena lebih besar dari 0,6.

Berdasarkan hasil analisis data, jika dilihat dari nilai loading estimate yang diperoleh oleh masing-masing indikator, indikator Efficiency of Inventory Management/EIM item pernyataan "Saya selalu melakukan persiapan anggaran persediaan" paling dominan merefleksikan variabel Keputusan penempatan dana untuk modal kerja.

Hasil pengujian menunjukkan Keputusan penempatan dana untuk modal kerja manajer sekaligus pemilik UKM paling direfleksikan oleh indikator investasi Efficiency of Inventory Management/EIM item pernyataan "Saya selalu melakukan persiapan anggaran persediaan" dengan nilai rerata 3,91. Artinya tidak semua manajer sekaligus pemilik UKM melakukan persiapan anggaran persediaan . 


\subsubsection{Model Struktural}

Dalam model struktural ini, diuji 2 (dua) hipotesis. kedua hipotesis diterima dan ditunjukkan oleh gambar 4.1.

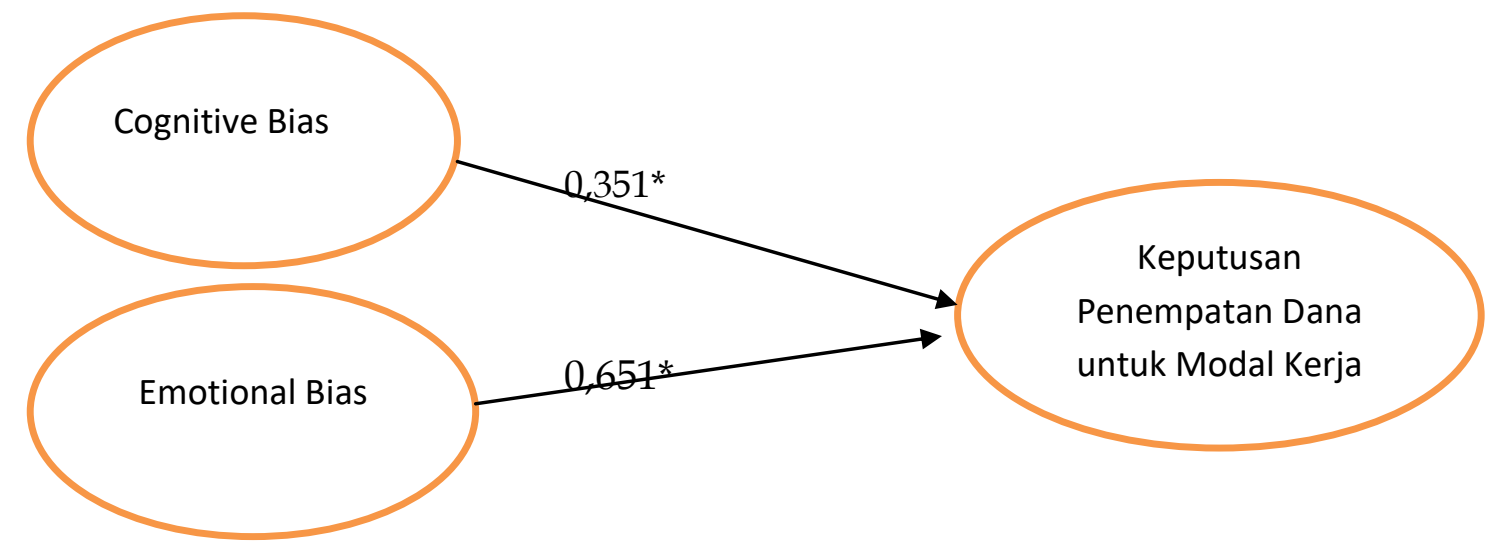

* : signifikan pada $a=0,05$

Pengujian hipotesis sebagai berikut:

a. Nilai koefisien pengaruh cognitive bias terhadap keputusan penempatan dana untuk modal kerja sebesar 0,3351 dan signifikan, artinya semakin tinggi cognitive bias manajer sekaligus pemilik UKM maka semakin tepat dalam keputusan penempatan dana untuk modal kerja.

b. Nilai koefisien pengaruh emotional bias terhadap keputusan penempatan dana untuk modal kerja sebesar 0,651 dan signifikan, artinya semakin tinggi emotional bias manajer sekaligus pemilik UKM maka semakin tepat dalam keputusan penempatan dana untuk modal kerja.

\subsection{Pembahasan Hasil Penelitian}

\subsubsection{Pengaruh Cognitive Bias terhadap Keputusan Penempatan Dana untuk Modal Kerja}

Cognitive Bias berpengaruh positif dan signifikan terhadap keputusan penempatan dana yang dilakukan oleh pemilik sekaligus pemilik UKM.Artinya semakin percaya diri, yakin dapat mengerjakan sesuatu dengan lebih baik dan yakin dapat mempengaruhi hasil maka akan semakin tepat dalam pengambilan keputusan penempatan dana untuk modal kerja. Hal ini berarti semakin semakin tinggi cognitive bias manajer sekaligus pemilik UKM maka semakin tepat dalam keputusan penempatan dana untuk modal kerja. Hal ini didukung oleh keyakinan para manajer dalam mengantisipasi jika terjadi masalah ditengah jalan terutama dalam keputusan penempatan dana untuk modal kerja. Pengaruh tersebut sesuai dengan pendapat para ahli menyatakan, bahwa faktor psikologis memiliki pengaruh yang besar bagi seseorang dalam mengambil keputusan (Pradhana, 2018). Faktor psikologis ini dijelaskan dalam prospect theory bahwa manusia tidak selalu berperilaku secara rasional dalam pengambilan keputusan keuangan. Adanya faktor psikologis dalam pengambilan keputusan ini terjadi pada masa pandemic covid 19. Ada kecenderungan bagi para pemilik UKM yang tidak terbiasa menghadapi pandemic berfikir irasional dalam pengambilan keputusan investasi. Kecenderungan ini dilakukan berdasarkan pengalaman-pengalaman yang diperoleh selama melakukan operasional perusahaaan. Hal ini dilatarbelakangi oleh usia sebagian besar responden berusia produktif, sebagian besar laki-laki, tingkat pendidikan sebagian besar SMA dan Perguruan Tinggi, serta sebagian responden lama usahanya lebih dari 15 (limabelas) tahun.

Temuan ini memperluas studi tentang keuangan perilaku. Lebih jelasnya, penelitian ini menghasilkan temuan bahwa cognitive bias yang dimiliki oleh manajer UKM yang dominan direfleksikan oleh indikator illusion of control bias berpengaruh positif dan signifikan terhadap 
keputusan penempatan dana untuk modal kerja. Hasil Penelitian ini sesuai dengan penelitian yang dilakukan oleh Qadri dan Shabbir (2014).

\subsubsection{Pengaruh Emotional Bias terhadap Keputusan Penempatan Dana untuk Modal Kerja}

Emotional Bias berpengaruh positif dan signifikan terhadap keputusan penempatan dana untuk modal kerja yang dilakukan oleh pemilik sekaligus pemilik UKM. Hal ini berarti semakin tinggi emotional bias yang berkaitan dengan keyakinan untuk menghindari kerugian daripada mendapatkan keuntungan serta lebih menyukai tidak adanya perubahan maka semakin tepat dalam pengambilan keputusan yang dilakukan oleh pemilik UKM dalam penempatan dana untuk modal kerja. Emotional bias direfleksikan oleh regret aversion bias dengan cara menghindari dari kerugian yang sama yang berkaitan dengan keputusan penempatan dana untuk modal kerja. Secara psikologis, emosi dan kognisi secara terus menerus berinteraksi di dalam otak dan masing-masing dapat memiliki potensi untuk membiaskan atau meningkatkan pengambilan keputusan tergantung pada jenis keputusan yang akan diambil (Lerner et al., 2015). Adanya pandemic covid 19 dapat membuat pemilik UKM relatif tidak mampu berfikir rasional dan terjebak dalam bias (irasional). Selain itu, para pelaku UKM lebih sering melakukan olah informasi secara cepat agar bisa mendapatkan kesimpulan maupun hasil yang diperoleh secara cepat pula, sehingga terkadang menimbulkan kesalahan-kesalahan penilaian sehingga menimbulkan bias-bias perilaku atau disebut juga bias psikologi pelaku keuangan. Bias-bias perilaku ini terjadi karena sesuai dengan teori behavioral finance yang mengemukakan bahwa tidak sepenuhnya pelaku ekonomi berlaku rasional dalam hal pengambilan keputusan keuangan. Hal ini juga dilatarbelakangi oleh usia sebagian besar responden berusia produktif, sebagian besar laki-laki, tingkat pendidikan sebagian besar SMA dan lama usaha lebih dari 15 (lima belas) tahun.

Temuan ini memperluas studi tentang keuangan perilaku. Lebih jelasnya, penelitian ini menghasilkan temuan bahwa emotional bias yang dimiliki oleh manajer UKM yang dominan direfleksikan oleh indikator regret aversion bias berpengaruh positif dan signifikan terhadap pengambilan keputusan penempatan dana untuk modal kerja. Hasil penelitian ini sesuai dengan yang dilakukan Khilar and Singh (2020) yang menyatakan emotional bias berpengaruh terhadap keputusan investasi. Duxbury (2015) yang menyatakan emotional bias berpengaruh poitif dan signifikan terhadap pengambilan keputusan investasi

\section{KESIMPULAN DAN SARAN}

\subsection{Kesimpulan}

Berdasarkan pengujian hipotesis, hasil pembahasan dan temuan penelitian, dapat dikemukakan beberapa kesimpulan sebagai berikut:

1. Cognitive Bias berpengaruh positif dan signifikan terhadap keputusan penempatan dana yang dilakukan oleh pemilik sekaligus pemilik UKM.Artinya semakin percaya diri, yakin dapat mengerjakan sesuatu dengan lebih baik dan yakin dapat mempengaruhi hasil maka akan semakin tepat dalam pengambilan keputusan penempatan dana untuk modal kerja

2. Emotional Bias berpengaruh positif dan signifikan terhadap keputusan penempatan dana untuk modal kerja yang dilakukan oleh pemilik sekaligus pemilik UKM. Hal ini berarti semakin tinggi emotional bias yang berkaitan dengan keyakinan untuk menghindari kerugian daripada mendapatkan keuntungan serta lebih menyukai tidak adanya perubahan maka semakin tepat dalam pengambilan keputusan yang dilakukan oleh pemilik UKM dalam penempatan dana untuk modal kerja. 


\subsection{Saran-saran}

Berdasarkan pada hasil dan kesimpulan penelitian ini, dapat dikemukakan saransaran yang menjadi rekomendasi pada penelitian berikutnya.

1. Penelitian yang akan datang diharapkan sampel penelitian tidak hanya terbatas pada UKM gerabah yang ekspor saja, karena masih banyak UKM ekspor yang berkembang di masyarakat, seperti UKM kerajinan bambu dan kayu.

2. Penelitian yang akan datang, diharapkan tidak saja pada profit organization tapi juga pada non profit organization, aparat pemerintah dan rumah tangga, sehingga bisa diketahui bagaimana keuangan perilaku pada objek penelitian yang lain.

\section{DAFTAR PUSTAKA}

Akhtar, Sharmin and Liu, Yanping. 2018. SME Managers and Financial Literacy; Does Financial Literacy Really Matter ?. Journal of Public Administration and Governance, Vol 8, No. 3, pp. 353-373

Amanah, Rahadian dan Iradianty, 2016, Pengaruh Financial Knowledge, Financial Attitudes dan External Locus of Control terhadap Personal Financial Management Behavior pada Mahasiswa S1 Universitas Telkom, e-Proceeding of Management, Vol-3, No. 12. Agustus 2016, Page 1228

De Bondt, W. et al. 2008. Behavioral Finance: Quo Vadis ?. Journal of Applied Finance; Fall 2008; 18, 2; ABI/INFORM Research.

Duxbury, Derren, 2015. Behavioral finance: insights from experiments I: theory and financial markets. Review of Behavioral Finance, Vol. 7 (1): 78 - 96

Eagly and Chaiken. 1993. The Psychology of Attitudes. Fort Worth, TX: Harcourt, Brace, \& Janovich, 794 pp.

Forbes, William.2009. Behavioural Finance. First Edition. John Wiley \& Sons Ltd.

Gumanti, Ary Tatang. 2009, Behavior Finance: Suatu Telaah. Usahawan No. 1/Th, XXXVIII

Herdjiono dan Damanik. 2016. Pengaruh Financial Atitude, Financial Knowledge, Parental Income terhadap Financial Management Behavior. Jurnal Manajemen Teori dan Terapan.Tahun 9. No. 3, Desember 2016

Idrus, M. Syafiie. 1999. Strategi Pengembangan Kewirausahaan (Entreprenuership) dan Peranan Perguruan Tinggi dalam Rangka Membangun Keunggulan Bersaing (Competitive Advantage) Bangsa Indonesia pada Millenium Ketiga, Makalah tidak dipubilkasikan, Universitas Brawijaya Malang.

Jermias, Johnny and Gani, Lindawati. 2005. Ownership Structure, Contingent-fit, and Businessunit Performance: A Research Model and Empirical Evidence. The International Journal of Accounting, vol. 40, pp. 65-85

Kartini dan Nuris, F Nugraha, 2016. Pengaruh Illusion of Control dan Emotion terhadap pengambilan keputusan investasi pada Investor di Yogyakarta. Jurnal Inovasi dan Kewirausahaan.4(2):115-112

Khilar And Singh. 2020. Role Of Emotional Bias On Investment Decision From Behavioural Finance Perspective. International Journal Of Scientific \& Technology Research, volume 9, Issue 03, pp. 3457 - 3460.

Klontz, Britt, Mentzer and Klontz. 2011. Money Beliefs and Financial Behaviors: Development of the Klontz Money Script Inventory, The Journal of Financial Therapy. Volume 2, Issue 1.

Lerner, Jennifer S., Ye Li, Piercarlo Valdesolo, and Karim S. Kassam. 2015. Emotion and Decision Making. Annual Review of Psychology 66, No. 1, Page 799-823 
Lianto dan Elizabeth. 2017. Analisis Pengaruh Financial Attitude, Financial Knowledge, Income terhadap Financial Behavior di Kalangan Ibu Rumah Tangga Palembang (Studi Kasus Kecamatan Ilir Timur I). http:/ / eprints.mdp.ac.id/2365/. Diakses 22 November 2019

Mien, Nguyen Thi Ngoc and Thao, Thran Puong. 2015. Factors Affecting Personal Financial Management Behaviors : Evidence from Vietnam.Proceedings of the Second Asia-Pacific Conference on Global Business, Economics, Finance and Social Sciences (AP15Vietnam Conference).

Nababan dan Sadalia (2012), Analisis Personal Financial Literacy dan Financial Behavior Mahasiswa Strata I Fakultas Ekonomi Universitas Sumatera Utara, Jurnal Online, http://jurnal.usu.ac.id/index.php/jmim/article/view/651.

Nyamao, Patrick, Martin, Odondo and Simeyo. 2012. Effect of working capital management practices on financial performance: A study of small scale enterprises in Kisii South District, Kenya. African Journal of Business Management, Vol. 6, pp. 5807-5817.

Qadri, Syad usman and Shabbir, Mohsin. 2014. An Empirical Study of Overconfidence and Illusion of Control Biases, Impact on Investor's Decision Making: An Evidence from ISE. European Journal of Business and Management, Vol.6, No.14, 20

Ricciardi V. and Simon, H, K. 2000. What is Behaviour in Finance . Business, Education, and Technology Journal, Vol. 2, No. 2, pp. 1-9.

Sherin. 2007. Beyond Greed and Fear: Understanding Behaviour Finance and Psychology of Investing, Harvard business School Press, Boston, USA

Solimun. 2012. Pemodelan Persamaan Struktural: Generalized Structured Component Analysis GSCA. Materi Pelatihan Statistika Multivariat. Fakultas MIPA. Universitas Brawijaya.

Sugiyono. 2008. Metode Penelitian Bisnis (Pendekatan Kuantitatif, Kualitatif dan $R$ \& D). CV. Alfabeta. Bandung

Supramono dan Putlia, Nancy. 2010. Persepsi dan Faktor Psikologis dalam Pengambilan Keputusan Hutang. Jurnal Keuangan dan Perbankan, Vol. 14, No. 1 Januari 2010, hal. 2435.

Pompian, Michael M.2006. Behavioral Finance and Wealth Management. John Wiley \& Sons, Inc. New Jersey.

Van Horne, James C. 2002. Financial Management and Policy. Twelfth Edition. Prentice Hall Upper Saddle River. New Jersey.

Wiharno, Herma. 2018. Pengaruh Financial Knowledge, Financial Behavior dan Financial Attitudeterhadap Personal Financial Management. JRKA Volume 4 Isue 1, Februari 2018: 6476.

Wulandari dan Iramani. 2014. Studi Experienced Regret, Risk Tolerance, Overconfidance Dan Risk Perception Pada Pengambilan Keputusan Investasi Dosen Ekonomi. Journal of Business and Banking. Volume 4, No. 1, May 2014, pages 55 - 66

https://diskop.ntbprov.go.id/data/2020/10/REKAPITULASI-DATA-JUMLAH-UMKM-NTB2019.pdf. Diakses 10 November 2021

http://lipi.go.id/berita/survei-kinerja-umkm-di-masa-pandemi-covid19/22071. Di akses 10 November 2021 